\title{
Resilience of Invaded Riparian Landscapes: The Potential Role of Soil-Stored Seed Banks
}

\author{
Farai Tererai $\cdot$ Mirijam Gaertner $\cdot$ Shayne M. Jacobs • \\ David M. Richardson
}

Received: 21 November 2013/Accepted: 12 September 2014/Published online: 23 September 2014

(c) Springer Science+Business Media New York 2014

\begin{abstract}
We investigated the potential role of soil-stored seed banks in driving vegetation recovery under varying intensities of invasion by the alien tree Eucalyptus camaldulensis along the Berg River in South Africa's Western Cape Province. We asked: How do richness, diversity, and composition of soil-stored seed banks vary with invasion intensity? What is the difference between the seed banks and above-ground vegetation with respect to species richness, diversity, composition, and structure? To what extent do soil-stored seed banks provide reliable sources for restoring native plant communities? Through a seedlingemergence approach, we compared seedling density, richness, and diversity in plots under varying Eucalyptus cover. Seed bank characteristics were also compared with those of the above-ground vegetation. Except in terms of diversity and density, the richness and composition of native species
\end{abstract}

Electronic supplementary material The online version of this article (doi:10.1007/s00267-014-0374-z) contains supplementary material, which is available to authorized users.

F. Tererai $(\bowtie) \cdot$ M. Gaertner $\cdot$ D. M. Richardson

Department of Botany \& Zoology, Centre for Invasion Biology,

Stellenbosch University, Private Bag X1, Matieland 7602,

South Africa

e-mail: ftererai@gmail.com

M. Gaertner

e-mail: gaertnem@sun.ac.za

D. M. Richardson

e-mail: rich@sun.ac.za

Present Address:

F. Tererai

African Climate and Development Initiative (ACDI), University

of Cape Town, Private Bag X3, Rondebosch, Cape Town 7700,

South Africa varied significantly among invasion conditions. Despite the paucity of native tree and shrub species in the seed bank, it was more diverse than extant vegetation. Some species occurred exclusively either in the seed bank or in the above-ground vegetation. Although this ecosystem has been degraded by several agents, including Eucalyptus invasion, soil-stored seed banks still offer modest potential for driving regeneration of native plant communities, but secondary invasions need to be managed carefully. Remnant populations of native plants in the above-ground vegetation remaining after $E$. camaldulensis clearing provide a more promising propagule source for rapid regeneration. Further work is needed to elucidate possible effects of invasion on successional pathways following E. camaldulensis removal and the effects of hydrochory on seed bank dynamics.

Keywords Biological invasions - Ecosystem resilience . Eucalyptus camaldulensis · Restoration · Secondary invasions $\cdot$ Seed recruitment

\footnotetext{
S. M. Jacobs

Department of Conservation Ecology and Entomology,

Stellenbosch University, Private Bag X1, Matieland 7602,

South Africa

e-mail: sjacobs@sun.ac.za

S. M. Jacobs

Stellenbosch University Water Institute, Faculty of Science,

Stellenbosch University, Private Bag X1, Matieland 7602,

South Africa
} 


\section{Introduction}

Riparian zones are river and stream margins and often characterized by a distinct flora that differs in diversity, structure, and function from that in adjacent terrestrial ecosystems (Naiman and Décamps 1997; Poff et al. 2011). The flora of riparian zones provides important functions (e.g., riverbank stabilization) and services (e.g., flood attenuation) (Hood and Naiman 2000; Hooper et al. 2005). These functions and services are threatened by ecosystem degradation in many parts of the world (Baattrup-Pedersen et al. 2012), often eroding ecosystem resilience. Resilience, the ability (Wali 1999), or time taken (Mitchell et al. 2000) for an ecosystem to recover to some acceptable structural or functional reference level is often inextricably linked to disturbance (Richardson et al. 2007). The agents of ecosystem degradation in riparian zones are both natural (dynamic hydrology, climate change) and anthropogenic (agricultural activities and water abstraction) (Naiman et al. 1993; Kauffman et al. 1995; Décamps et al. 2004; Bottollier-Curtet et al. 2013). The inherent disturbances of riparian zones create opportunities for recruitment of invasive alien plants (IAPs) (Holmes et al. 2005; Poff et al. 2011; Sîrbu et al. 2012), and these may further threaten ecosystem integrity (Gaertner et al. 2009; Vilà et al. 2011). Besides high human population density, urbanization and agriculture (Underwood et al. 2009), one of the most commonly reported threats to plant diversity in the Mediterranean-type ecosystems, are plant invasions (Richardson et al. 1989; Vitousek et al. 1996; Levine et al. 2003; Pyšek and Richardson 2010; Vilà et al. 2011). Ecological restoration presents opportunities to restore degraded riparian habitats by breaking the cycle of degradation in plant community diversity and ecosystem function (Brudvig 2011). However, since ecosystem degradation is a compound effect of various perturbation agents, teasing out the effects of a single agent such as invasion is difficult, and this complicates restoration efforts (Gaertner et al. 2011; Poff et al. 2011).

Many studies have compared invaded and uninvaded sites to evaluate the effects of plant invasions on standing vegetation (Levine et al. 2003; Gaertner et al. 2009; Vilà et al. 2011; Gioria et al. 2014). However, the above-ground vegetation forms only a part of the overall plant diversity (Margalef 2002). Soil-stored seed banks, a key component of ecosystem resilience, play a significant role in restoration (Holmes and Richardson 1999; Williams et al. 2008; Gioria et al. 2012; Heelemann et al. 2013) yet are also threatened by the agents of degradation in riparian zones (Poff et al. 2011). Thus, there is need for a better understanding of the potential role that soil-stored seed banks could play in restoration of riparian habitats (Landenberger and McGraw 2004; Gioria et al. 2014).
In many degraded ecosystems worldwide where invasive alien plants are one of the agents of disturbance, "clearing" is a widely applied management action (Manchester and Bullock 2000; Beater et al. 2008; Shafroth and Briggs 2008; Flory and Clay 2009). However, simply removing the stressor often fails to stimulate the recovery of native species or to restore the functionality of degraded ecosystems (Galatowitsch and Richardson 2005; Le Maitre et al. 2011; Gaertner et al. 2012). After removal of invasive alien plants, native species may regenerate from remnant native species that co-existed with the invader, from the seed bank and through propagules dispersed from surrounding vegetation and external sources (Bakker et al. 1996; Landenberger and McGraw 2004; French et al. 2011). There are several factors that could account for recruitment limitation after clearing of invasive species. In densely invaded habitats, including riparian zones, which are often associated with suppressed native vegetation, post-clearing recovery relies on soil-stored seeds (Musil and De Witt 1990; Williams et al. 2008; Marchante et al. 2011; Li et al. 2012). However, some native species may have transient or short-lived seed banks (Thompson and Grime 1979; Thompson et al. 1997) or may not form any seed bank (Richardson et al. 2007; Fourie 2008; Vosse et al. 2008). Invasive trees often form almost complete monocultures, thereby disrupting inputs to the soil-stored seed bank by native species; over time, this leads to the attrition of previously deposited native seed stores (Gioria et al. 2012, 2014). Native plants that occur in heavily invaded ecosystems die prematurely or produce few or no seeds (del Moral and Muller 1970; Holmes and Cowling 1997; Levine et al. 2003; Vilà and Gimeno 2007). This often translates into a depauperate seed bank which limits recruitment (Gioria and Osborne 2009; French et al. 2011).

The management action needed for degraded riparian habitats depends on the suite of agents of disturbance and type and extent of damage (Poff et al. 2011). While invasion is part of the disturbance, recovery or restoration of resident plant communities may partly depend on the invader and the invaded habitat (Gaertner et al. 2012; Gioria et al. 2012). Riparian zones in the Western Cape of South Africa are severely degraded by invasive trees such as Eucalyptus camaldulensis Dehnh. (Forsyth et al. 2004; Tererai et al. 2013). We investigated regeneration potential from soil-stored seed banks on degraded sites in these riparian ecosystems under different invasion conditions (uninvaded, lightly, moderately, and heavily invaded) and posed the following questions: (1) Is the richness, diversity, and composition of the soil-stored seed banks affected by invasion intensity?; (2) Is there a difference in species richness, diversity, composition, and structure between the seed bank and above-ground vegetation across invasion conditions?; (3) Does the soil-stored seed bank provide 
varying potential for regeneration of composition and structure of native plant community across invasion conditions? We evaluated the results to determine guidelines for managing degraded riparian habitats.

\section{Materials and Methods}

\section{Study Site}

Our study was conducted on a 92-km stretch of the main stem of the Berg River, in the upper catchment, between the towns of Hermon and Franschhoek, north-east of Cape Town in South Africa's Western Cape province (Fig. 1). The area has a Mediterranean-type climate with warm dry summers and cool wet summers with an annual average rainfall of about $550 \mathrm{~mm}$ (Tererai et al. 2013). The average annual temperature minima and maxima are 11 and $22{ }^{\circ} \mathrm{C}$, respectively. The whole river stretch has been invaded by alien trees, mainly $E$. camaldulensis for c. 50 years, but was interspaced with individuals of Acacia mearnsii De Wild. and Populus spp. (poplars) in some locations (Tererai et al. 2013). The eucalypts are selfsown escapees from original planting sites where they were grown for different purposes including timber, fuelwood, and shelterbelts (Tererai 2012). Dominant native woody riparian vegetation includes trees and shrubs of Diospyros glabra (L.) De Winter, Kiggelaria africana L., Olea europaea subsp. africana (Mill.) P.S. Green, Podocarpus elongatus (Aiton) L'Herit. ex Pers, and Searsia angustifolia (L.) F.A. Barkley which are now mainly confined to small pockets or isolated individuals within stands of E. camaldulensis (Ruwanza et al. 2013; Tererai et al. 2013).

The Berg River riparian ecosystem is under different kinds of natural and anthropogenic pressures. As a perennial river, it experiences frequent flooding in winter every year (Tererai et al. 2013). The hydrological regime is influenced by water abstraction for irrigated agriculture which constitutes about $65 \%$ of the catchment (Geldenhuys 2008). Agricultural activities adjacent to the river can alter river sediment regime (Richardson et al. 2007and

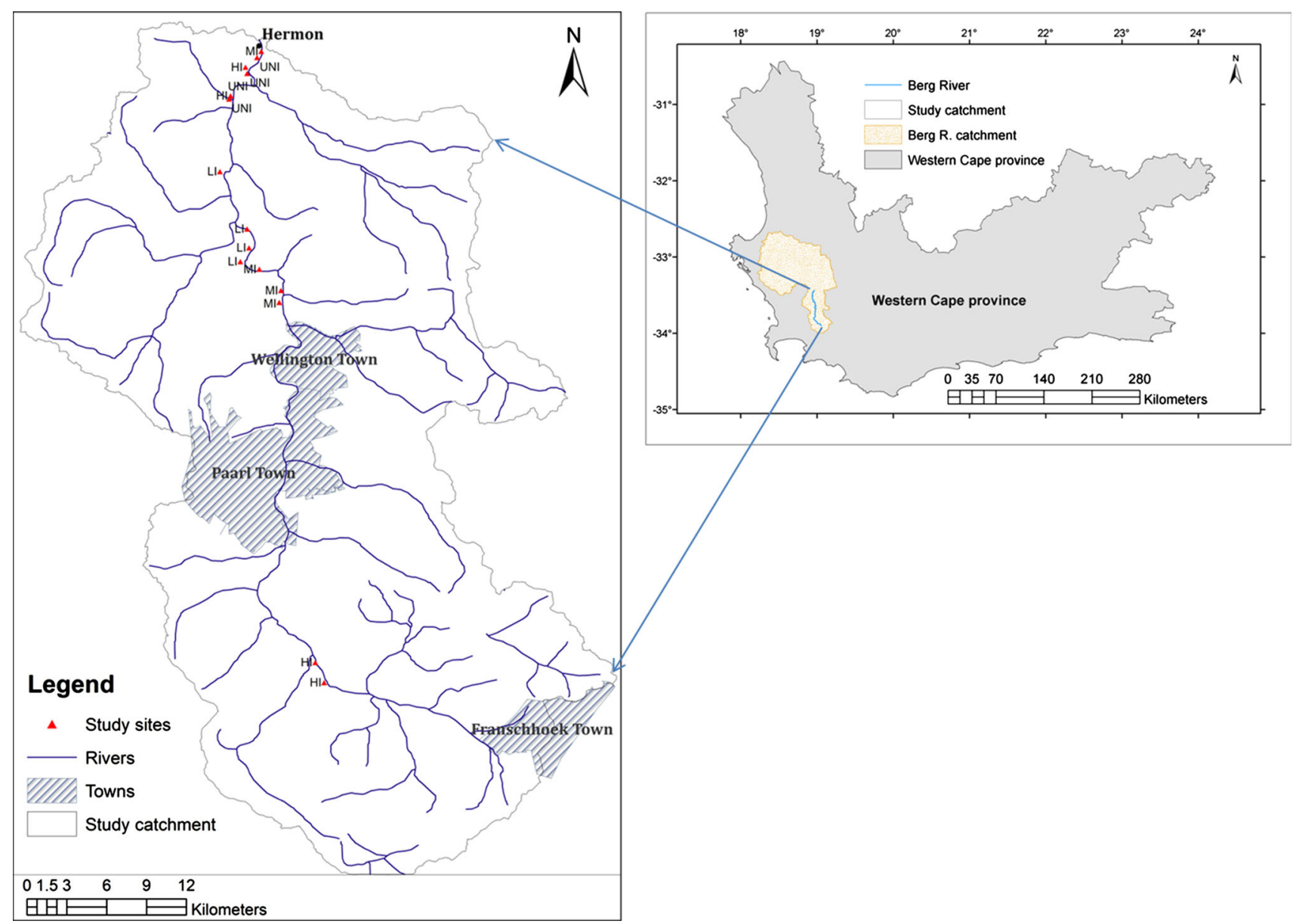

Fig. 1 Distribution of study sites (UNI uninvaded, $L I$ light invasion, $M I$ moderate invasion, $H I$ heavy invasion) along the Berg River between the towns of Hermon and Franschhoek; Western Cape, South Africa 
Fig. 2 Sketch of study design showing the orientation of sites and plots along the Berg River, Western Cape, South Africa. Each site measured $10 \mathrm{~m}$ along the river and $20 \mathrm{~m}$

perpendicular to the river. Each site was then divided into $10 \times 5 \mathrm{~m}$ plots for data collection and analysis purposes. The location and order of the different invasion conditions and their replicates were random depending on where suitable sites were found. The dotted lines marking the riparian zone only show the average width at any site along the river, not the full extent

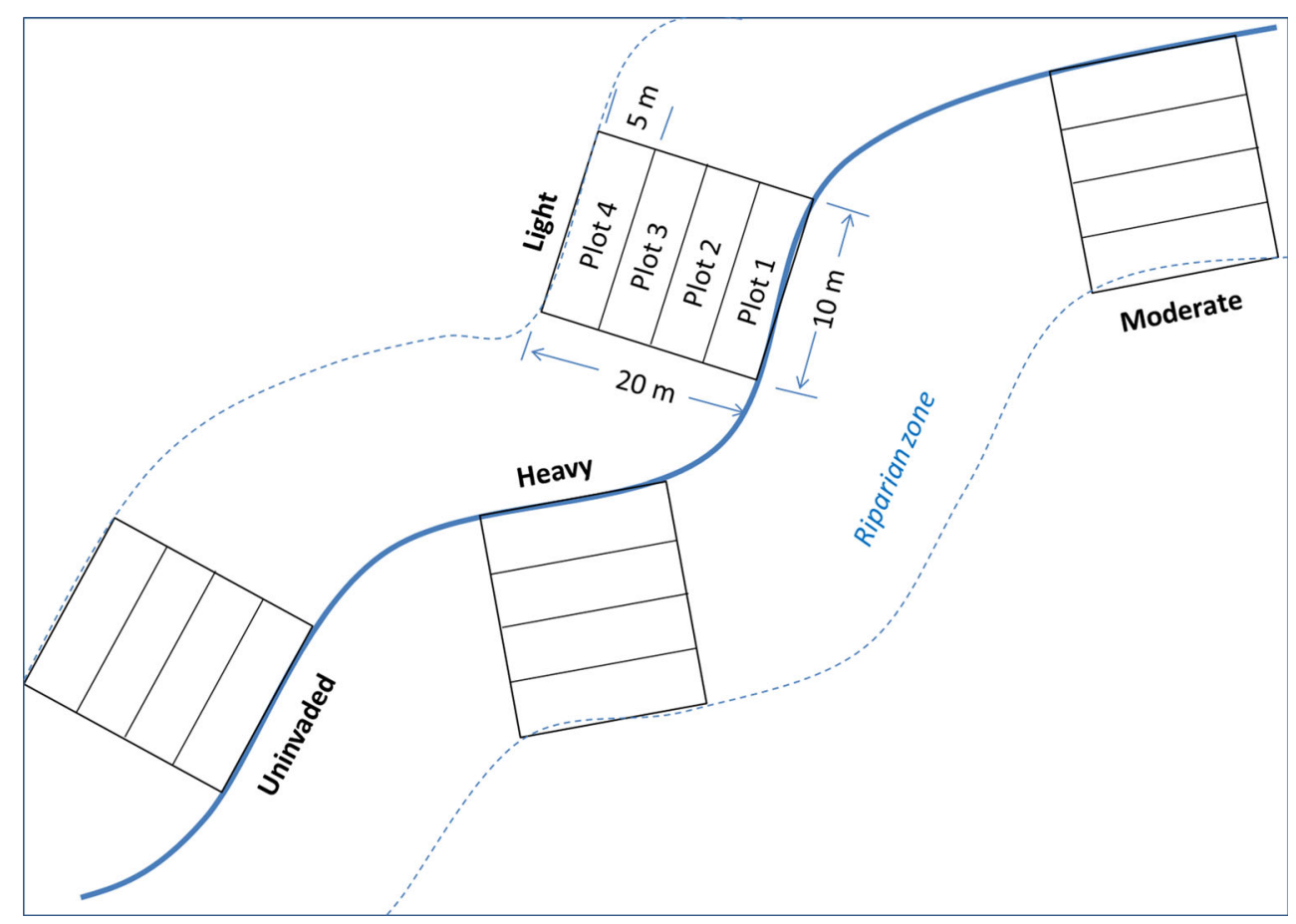

references therein). The Berg River Dam which was constructed in 2007 also regulates the hydrological regime.

\section{Study Design}

We studied soil-stored seed banks and above-ground vegetation changes in four categories of invasion (hereafter referred to as "invasion conditions"), each with three replicates ( $n=12$ sites): "uninvaded-UNI" (0-24\%), "light-LI" (25-49\%), "moderate-MI" (50-74\%), and "heavy-HI" ( $\geq 75 \%$ cover of E. camaldulensis). Of all agents of disturbance in the Berg River (including invasion, agricultural activities, water abstraction, and flooding), we selected the factor "invasion" to categorize sites because it clearly differentiated sites. Sites measured $10 \mathrm{~m}$ along the river and spanned $20 \mathrm{~m}$ of the riparian zone, with plots in 5-m widths perpendicular to the river (Fig. 2). The sites were randomly located on both sides of the river. For each invasion category, we sampled the same conditions (soil types and vegetation types-grass patches, shrub and forest in which E. camaldulensis achieved dominance) to ensure the plots were comparable. A few individuals of E. camaldulensis occurred in two of the "uninvaded" sites as we could find no sites that were totally free of this species. "Pristine" reference sites, completely free of alien species, are extremely rare or simply do not exist in most ecosystems, including riparian habitats (Rosgen 1994; Richardson et al. 2007; Sieben and Reinecke 2008; Brewer and Menzel 2008). The above-ground vegetation was investigated in a separate study (Tererai et al. 2013), and only a subset of these data were used for the comparison of the seed bank with the above-ground vegetation in the present study.

Data Collection

Soil samples were collected from uninvaded, lightly, moderately, and heavily invaded plots. Sampling was done late summer (February, 2011), a time we observed seed rain of majority of the plants in order to capture both the long buried and recently dispersed components of the seed bank (Walck et al. 2005; Vilà and Gimeno 2007; Fisher et al. 2008). Soil-stored seed bank sampling was deliberately conducted on the same sites and plots as the aboveground vegetation study (Tererai et al. 2013). This allowed a comparison to be made between characteristics of the soil-stored seed banks and above-ground vegetation. At each site, we sampled four $-5 \mathrm{~m} \times 10 \mathrm{~m}$ plots (Fig. 2). Three four-square meter sub-plots were located in each plot, making sure that similar conditions (see Sect. 2.2) were sampled. Five soil cores $(5-\mathrm{cm}$ diameter $\times 10-\mathrm{cm}$ depth) were randomly extracted. The five cores from each sub-plot were bulked to constitute a sample ( $n=3$ samples per plot, translating into 144 samples for the 12 sites). Sample bulking was done to reduce variability due to seed clustering or irregular distribution in the soil (Fisher et al. 2008). Detailed data collection methods for the aboveground vegetation are described in Tererai et al. 2013 but in short, individual and species counts and growth forms (graminoids, forbs, shrubs, and trees) were recorded. Plants were identified to species level using field identification 
books (Bromilow 2010), and a few were sent to a local herbarium-Compton Herbarium at the National Botanical Institute, Kirstenbosch, Cape Town, South Africa.

\section{Seedling-Emergence Assessment Experiment}

A seedling-emergence approach was used to estimate species richness and abundance per unit area (Thompson and Grime 1979). We selected the seedling-emergence approach over other methods because of its ability to assess seed availability, viability, and succession (Gioria et al. 2014). The experiment was set up in March, 2011 in a greenhouse with a transparent roof and walls of agro-shade netting material to enable simulation of diurnal temperatures. The soil was passed through a $10-\mathrm{mm}$ mesh to remove large stones, roots, and litter (Vilà and Gimeno 2007). The soils were placed in trays $\left(300 \times 270 \mathrm{~mm}^{2}\right)$ lined with hessian material to prevent seed and soil from washing out. The trays were given a smoke treatment in February to simulate a late summer fire, before the experiment was set up early March. The treatment was conducted by burning native plants in a drum and the smoke pumped into the tent containing the trays. The treatment has been shown to significantly enhance germination response in a variety of Western Cape plant taxa (Holmes and Cowling 1997; Holmes 2002). Five control trays, containing sterilized soil, were included, just in case any external seeds found their way in. The trays were regularly watered and rotated throughout the duration of the experiment. Seedling emergence was recorded every fortnight for nine months. For species that could not be identified immediately, duplicates were removed, and the species were grown until identifiable or until they flowered. Plants that had not flowered at the end of the experiment were compared with field herbarium specimens and identified to species level.

\section{Analysis}

Seedlings from the soil-stored seed bank were categorized into natives and aliens. The number of seedlings per tray was converted to density (number of seedlings per square meter) and compared according to invasion condition. Species richness $(S)$ and Shannon-Wiener's diversity index $\left(H^{\prime}\right)$ were used to measure seed bank community characteristics. To test for significant differences in species richness, diversity, and seedling density per tray in each invasion condition, we used two-way ANOVA since the data were normally distributed (using Kolmogorov-Smirnov test). While ANOVA results were significant, differences between pairs of invasion conditions were evaluated with Tukey's HSD unequal $n$ test. To determine differences in soil-stored seed bank composition among uninvaded, lightly, moderately, and heavily invaded sites, we adapted the statistical protocol of Gioria and Osborne (2009): i. PERMANOVA was performed to evaluate differences among invasion conditions; ii. Similarity percentages (SIMPER) were used to identify the species contributing the most to the observed differences; and iii. Analysis of similarity (ANOSIM) was used to measure the degree of species similarity among different invasion conditions within the seed bank. The data were first square root transformed before computing a resemblance matrix on which PERMANOVA, SIMPER, and ANOSIM analyses were based, using the Bray Curtis dissimilarity measure. In all analyses of variance, "invasion" was the fixed factor (four levels, each with three replicates-uninvaded, light, moderate, and heavy), and "site" was the random factor. The main response variable was seedling abundance of the following: i. "all" species, ii. "native" species, and iii. "alien" species. Univariate statistics were computed using Statistica v 10 (Statsoft Inc 2010; http://www.statsoft.com), while Multivariate statistics were computed in Primer v 6 and its add-on package, PERMANOVA + (PRIMER-E Ltd, Plymouth, UK).

To evaluate the degree of similarity in species composition between plots within the soil-stored seed bank and above-ground vegetation in each invasion condition, we computed the Sørensen's index calculated as follows: $S=2 C /(A+B)$, where $A$ (seed bank) and $B$ (the aboveground vegetation) are the numbers of species in each invasion condition, and $C$ is the number of species common in both (Henderson 2003). The relative frequency of species in each growth form (graminoids, forbs, shrubs, and trees) in the above-ground vegetation and seed bank was computed as a number of species in each growth form as a percentage of maximum possible number of species in all growth forms. Significant differences between either native and alien species or the above-ground vegetation and seed bank within the same invasion condition were tested using Mann-Whitney $U$ test after testing for normality with the Kolmogorov-Smirnov test.

\section{Results}

A total of 60 (50 genera and 30 families) and 47 (43 genera and 32 families) plant species were recorded in the soilstored seed bank and above-ground vegetation, respectively. Of the seed bank species, $33 \%$ were native (mainly shrubs, forbs and graminoids) compared to $40 \%$ in the above-ground vegetation (of which $40 \%$ were trees and shrubs). A total of 36 (13 native and 23 alien) species occurred in both the seed bank and above-ground vegetation. A total of 24 (7 native and 17 alien taxa) species occurred in the soil-stored seed bank only and 11 (6 native 
Table 1 ANOVA of the density of seedlings in soil samples collected from uninvaded, lightly, moderately, and heavily invaded sites along the Berg River, Western Cape South Africa

\begin{tabular}{|c|c|c|c|c|c|c|c|}
\hline \multirow[t]{2}{*}{ Source of variation } & \multirow[t]{2}{*}{$d f$} & \multicolumn{2}{|c|}{ Native species } & \multicolumn{2}{|l|}{ Alien species } & \multicolumn{2}{|c|}{ Eucalyptus } \\
\hline & & MS & $p$ & MS & $p$ & MS & $p$ \\
\hline Invasion & 3 & $136,919.70$ & 0.17 & $2,636,167.29$ & 0.000 & 99.31 & 0.20 \\
\hline Site & 2 & $84,273.03$ & 1.10 & $163,977.49$ & 0.38 & 32.99 & 0.59 \\
\hline Invasion $\times$ site & 6 & $205,176.34$ & 2.68 & $1,230,598.81$ & 0.000 & 201.68 & 0.01 \\
\hline
\end{tabular}

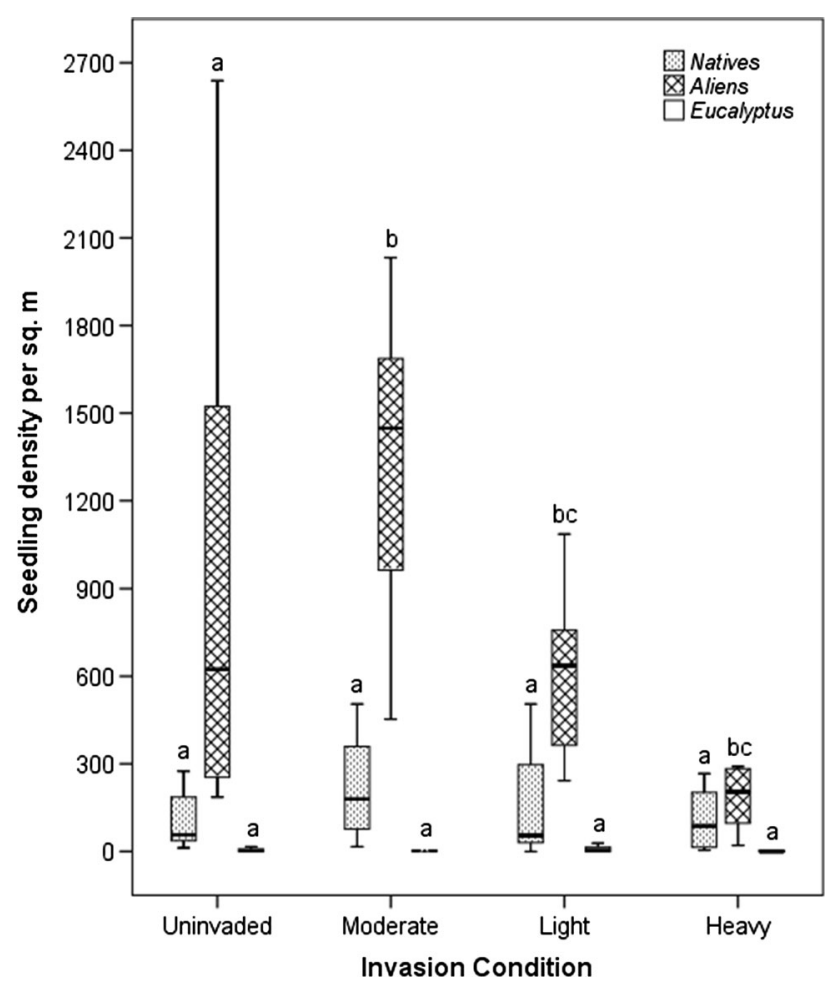

Fig. 3 Density (number of seedlings $\mathrm{m}^{-2}$ ) of seedlings (native species, alien species, and Eucalyptus camaldulensis) in the soil samples collected from uninvaded, lightly, moderately, and heavily invaded sites along the Berg River of the Western Cape, South Africa. The whiskers of each bar represent the non-outlier range, the bar represents the 25 th to the 75 th percentile, and horizontal line within the bar represents the mean. Superscripts ( $a, b$ and $c$ ) show results of Tukey HSD post hoc comparisons between all pairs of invasion conditions

and 5 alien taxa) species occurred in the above-ground vegetation only. More than half of the alien species in both the soil-stored seed bank and above-ground vegetation were forbs. There were no significant differences in species composition and diversity within replicates of each invasion condition.

Seed Bank Density, Richness and Diversity

There was no significant difference in the density of seedlings $\left(\mathrm{m}^{-2}\right)$ of native species [130 (UNI), $344(\mathrm{LI}), 165$ (MI), and $110(\mathrm{HI})]$ and E. camaldulensis [4 (UNI), 6 (LI),
8 (MI), and $2(\mathrm{HI})]$ between sites and invasion conditions (Table 1; Fig. 3). However, the interaction of invasion $\mathrm{x}$ site was significant for E. camaldulensis seedlings, although these occurred in very small numbers in the seed bank. Density of all alien seedlings [894 (UNI), 1428 (LI), 607 (MI), and 328 (HI)] differed significantly among invasion conditions and in the interaction invasion $\mathrm{x}$ site but not between sites (Table 1, Fig. 3). Pairwise comparisons showed no significant differences in native and $E$. camaldulensis seedling density between all pairs of invasion conditions (Fig. 3). However, alien species density differed significantly between pairs of invasion conditions; mean density of seedlings was the highest in lightly invaded sites. Acacia mearnsii recorded the highest seedling density of 40 (UNI), 804 (LI), 222 (MI), and 925 (HI) seedlings per $\mathrm{m}^{2}$.

The richness of native and alien species differed significantly among invasion conditions, and there was a significant interaction of invasion $\mathrm{x}$ site but not among sites (Table 2; Fig. 4a). The diversity of alien species differed significantly among invasion conditions, and there was a significant interaction of invasion $\mathrm{x}$ site but not among sites (Table 2; Fig. 4b). However, the diversity of natives did not differ among invasion conditions. The richness and diversity of native species were significantly lower than that of alien species in all invasion conditions (Fig. 4a, b). Pairwise comparisons showed that lightly and moderately invaded sites had significantly higher native and alien species richness (Fig. 4a). The diversity of native and alien species was largely similar between all pairs of invasion conditions, except moderately and heavily invaded sites for alien species that exhibited significant differences (Fig. 4b).

\section{Species Composition of Seed Banks}

A PERMANOVA analysis of "all," "native," and "alien" seed bank species showed that there were significant differences in species composition among invasion conditions $(F=6.99,4.47$, and 7.19, respectively). The Monte Carlo test showed significant differences between all possible pairs of invasion conditions $(p<0.001)$. There was a higher similarity (ANOSIM) of alien $(42 \%, p<0.01)$ than native $(23 \%, \quad p<0.01)$ species among invasion 
Table 2 ANOVA of native and alien species richness and diversity in soil samples collected from uninvaded, lightly, moderately, and heavily invaded sites along the Berg River, Western Cape South Africa

Fig. 4 Native and alien plant species a richness and b diversity (mean $\pm \mathrm{SE}$ ) of soil samples collected from uninvaded sites $(n=12)$, lowly $(n=12)$, moderately $(n=12)$, and heavily $(n=12)$ invaded sites along the Berg River, Western Cape, South Africa. Significant differences between all pairs of uninvaded, lowly, moderately, and heavily invaded sites were tested by Tukey HSD (depicted by $a$, $b$ and $c$ ), and significant differences between alien and native richness and diversity in each invasion condition were tested by Mann-Whitney $U$ test (depicted by $* p<0.05$,

$* * p<0.01$, and $* * * p<0.001)$

\begin{tabular}{|c|c|c|c|c|c|c|c|c|c|}
\hline \multirow[t]{3}{*}{ Source of variation } & \multirow[t]{3}{*}{$d f$} & \multicolumn{4}{|c|}{ Native species } & \multicolumn{4}{|c|}{ Alien species } \\
\hline & & \multicolumn{2}{|c|}{ Richness } & \multicolumn{2}{|c|}{ Diversity } & \multicolumn{2}{|c|}{ Richness } & \multicolumn{2}{|c|}{ Diversity } \\
\hline & & MS & $p$ & MS & $p$ & MS & $p$ & MS & $p$ \\
\hline Invasion & 3 & 6.97 & 0.002 & 0.16 & 0.31 & 149.14 & 0.000 & 0.81 & 0.00 \\
\hline Site & 2 & 0.58 & 0.60 & 0.14 & 0.33 & 13.08 & 0.09 & 0.30 & 0.16 \\
\hline Invasion $\times$ site & 6 & 3.53 & 0.01 & 0.20 & 0.17 & 43.31 & 0.000 & 0.71 & 0.001 \\
\hline
\end{tabular}
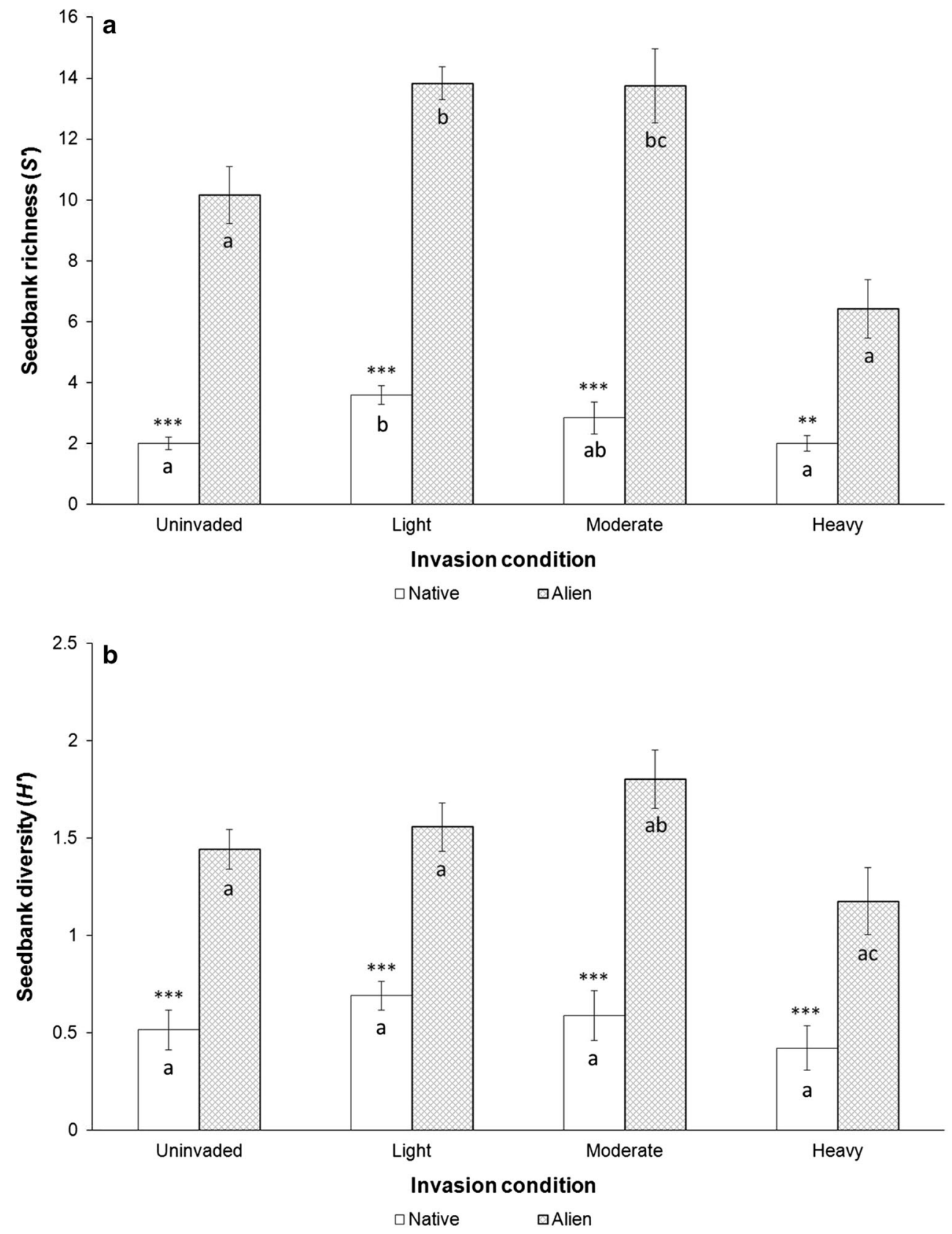

conditions. SIMPER results showed that the differences among the various invasion conditions are mainly explained by alien plant species, the major contributors to these differences being Solanum retroflexum Dunal. and $A$. mearnsii (explaining an average of $30 \%$ of detected differences in all invasion conditions except uninvaded sites) 
Table 3 ANOVA of the number of growth forms in soil samples collected from uninvaded, lightly, moderately and heavily invaded sites along the Berg River, Western Cape South Africa

\begin{tabular}{|c|c|c|c|c|c|}
\hline \multirow[t]{2}{*}{ Source of variation } & \multirow[t]{2}{*}{$d f$} & \multicolumn{2}{|c|}{ Vegetation } & \multicolumn{2}{|c|}{ Seed bank } \\
\hline & & MS & $p$ & MS & $p$ \\
\hline Invasion & 3 & 5.61 & 0.01 & 2.67 & 0.001 \\
\hline Site & 2 & 0.58 & 0.61 & 0.06 & 0.84 \\
\hline Invasion $\times$ site & 6 & 1.36 & 0.35 & 1.48 & 0.003 \\
\hline
\end{tabular}

Fig. 5 a Comparison of number of growth forms (mean $\pm \mathrm{SE}$ ) and $\mathbf{b}$ relative frequency $(\%)$ of species in each growth form in the seed bank and above-ground vegetation of soil samples collected from uninvaded $(n=12)$, lightly $(n=12)$, moderately, $(n=12)$ and heavily $(n=12)$ invaded sites. Significant differences were tested by Turkey HSD and that between seed bank and above-ground vegetation in the same invasion condition (asterisk) were tested by MannWhitney $U$ test after testing for normality of data with Kolmogorov-Smirnov
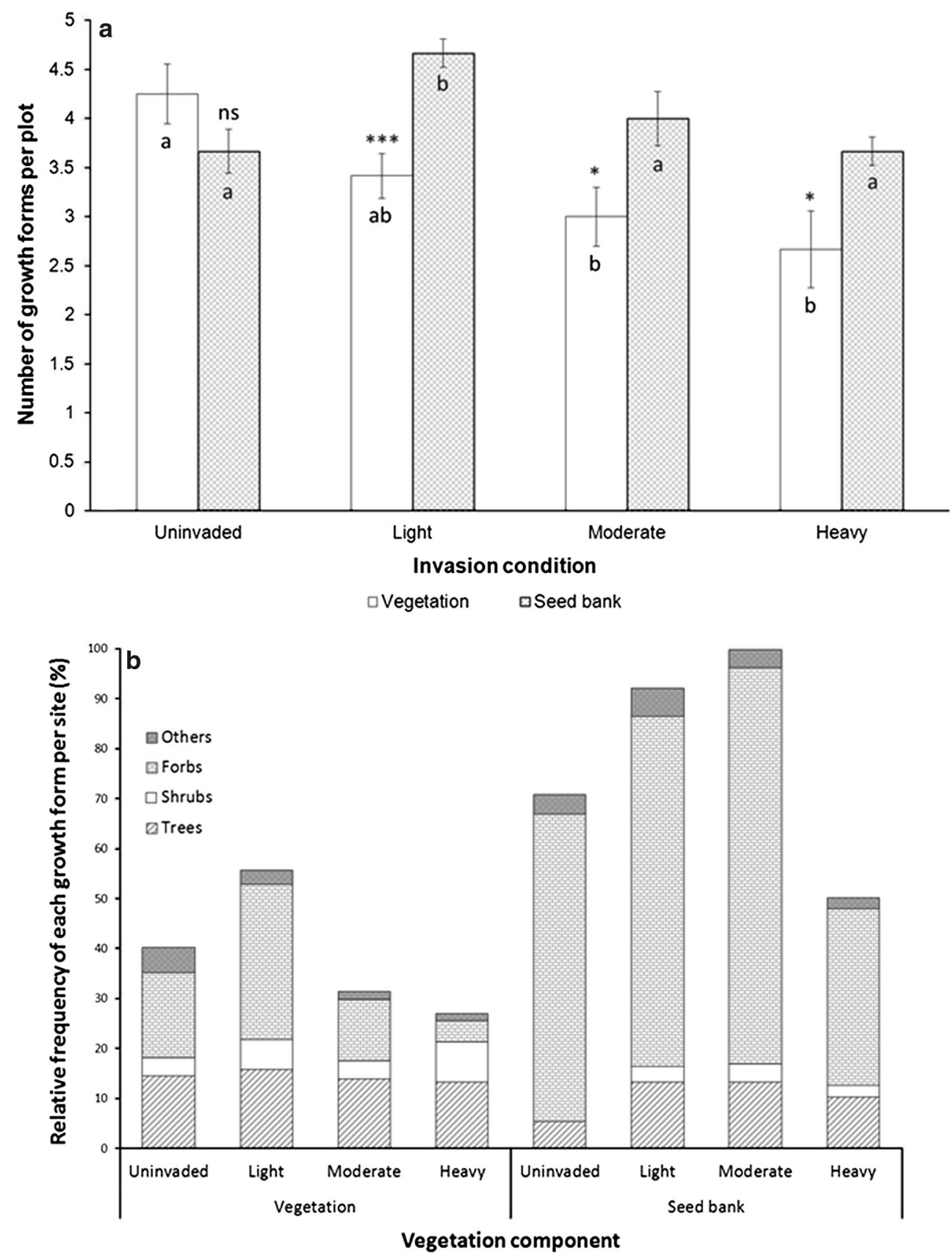
Table 4 Sørensen's community coefficient (S) for comparison between the above-ground vegetation and seed banks of riparian plots sampled in uninvaded sites and at sites with light, moderate and heavy invasions of Eucalyptus camaldulensis along the Berg River in Western Cape, South Africa

\begin{tabular}{llll}
\hline $\begin{array}{l}\text { Invasion } \\
\text { condition }\end{array}$ & $\begin{array}{l}\text { Site } \\
\text { number }\end{array}$ & $\begin{array}{l}\text { Sørensen's } \\
\text { index }\end{array}$ & $\begin{array}{l}\text { Average Sørensen's } \\
\text { index }\end{array}$ \\
\hline Uninvaded & 1 & 0.206 & 0.167 \\
& 2 & 0.173 & \\
Light & 3 & 0.122 & \\
& 1 & 0.374 & 0.367 \\
& 2 & 0.241 & \\
Moderate & 1 & 0.486 & \\
& 2 & 0.161 & 0.151 \\
& 3 & 0.088 & \\
Heavy & 1 & 0.204 & \\
& 2 & 0.077 & 0.192 \\
& 3 & 0.231 & \\
\hline
\end{tabular}

(see Appendix S3). A few native fynbos species, such as Stoebe plumosa (L.) Thunb. (a shrub occurring in all invasion conditions) and Aspalathus species (only occurring in uninvaded and heavily invaded sites) were recorded in the seed bank (see Appendix S1). Other native species in the seed bank included Senecio halimifolius (forb), Cyperus rotundus L. (graminoid), and Isolepis antarctica (L.) Roem. \& Schult. (sedge).

\section{Seed Bank: Above-Ground Vegetation Comparison}

The number of growth forms in the seed bank and aboveground vegetation differed among invasion conditions but not sites (Table 3; Fig. 5). However, the interaction invasion $\mathrm{x}$ site was only significant for seed bank (Table 3; $p<0.05)$. The seed bank exhibited significantly higher average number of growth forms per plot than that of the above-ground vegetation (Fig. 5a). Pairwise comparisons showed a decrease in mean number of growth forms of the above-ground vegetation as E. camaldulensis cover increased compared to the seed bank where mean number of growth forms were only significantly higher in lightly invaded sites (Fig. 5a). Generally, the seed bank had a higher frequency of forb species compared to the aboveground vegetation (Fig. 5b). The majority of the forb species were alien. Relatively fewer trees were recorded in the seed bank, and no shrubs were recorded in seed bank under uninvaded sites (Fig. 5b).

There was a generally low correspondence of species between the above-ground vegetation and soil-stored seed bank, with the highest similarity being recorded in lightly invaded sites (Table 4). There was a significantly higher richness and diversity of native species in the aboveground vegetation in uninvaded sites than in the seed bank, and alien species exhibited the exact opposite trend (Fig. 6a, b). Seed bank exhibited generally higher richness and diversity of native species in lightly, moderately, and heavily invaded sites compared to the above-ground vegetation (Fig. 6a). The seed bank also showed significantly higher richness and diversity of alien species in all invasion conditions. PERMANOVA revealed that species composition of both the above-ground vegetation and seed bank varied significantly among invasion conditions. Species similarity between invaded and uninvaded sites was, however, higher in the seed bank (48\%) than in the aboveground vegetation $(25 \%)$. Common tree and shrub species such as Kiggelaria africana, Diospyros glabra, and Olea europaea ssp. africana were more abundant in the aboveground vegetation than the seed bank. Native tree and shrub species such as Asparagus africanus Lam., Freylinia lanceolata Saccardo, Halleria lucida L., Maytenus oleoides (Lam.) Loes., and Salix mucronata Thunb. that are known to be able to recruit from seed were not recorded in the seed bank. Conversely, the native shrubs Erucastrum austroafricanum Al-Shehbaz \& S.I. Warwick, Selago canescens E.Mey., S. plumosa (L.) Thunb, and Helichrysum asperum (Thunb.) Hilliard \& B.L.Burtt were found in the seed bank but not in the above-ground vegetation.

\section{Discussion}

We investigated the resilience of soil-stored seed banks on degraded sites in riparian ecosystems under different invasion conditions (uninvaded, lightly, moderately and heavily invaded). The study was conducted in riparian ecosystems in the Western Cape Province, South Africa. Although this ecosystem has been degraded by several agents, including Eucalyptus invasion, soil-stored seed banks still potentially offer a reasonable contribution toward regenerating native plant communities. However, remnant native species are likely to make a more significant contribution to restoration, which should entail the removal of $E$. camaldulensis.

The natural regeneration of vegetation communities after disturbance is believed to lie in the potential contribution of buried native seed populations (Bakker et al. 1996, Thompson et al. 1997; Cui et al. 2013). In our study, native species density and diversity in the soil seed bank did not differ among invasion conditions, and all sites will hence require similar restoration actions. The similarity in density and diversity of native species may in part be explained by the homogenizing effect of flood pulsing that is characteristic of riparian zones (Richter and Stromberg 2005; Vosse et al. 2008; Baattrup-Pedersen et al. 2012). 
Fig. 6 The above-ground vegetation and seed bank characteristics a mean plot species richness, b mean plot diversity recorded in the seed bank experiment and aboveground vegetation study both conducted on 12 sites along the Berg River, Western Cape, South Africa. Significant differences between pairs of uninvaded, lightly, moderately, and heavily invaded sites were tested using the non-parametric Mann-Whitney $U$ test, since all data were not normally distributed and are depicted by $* p<0.05 ; * * p<0.01$; and $* * * p<0.001, n s$ not significant
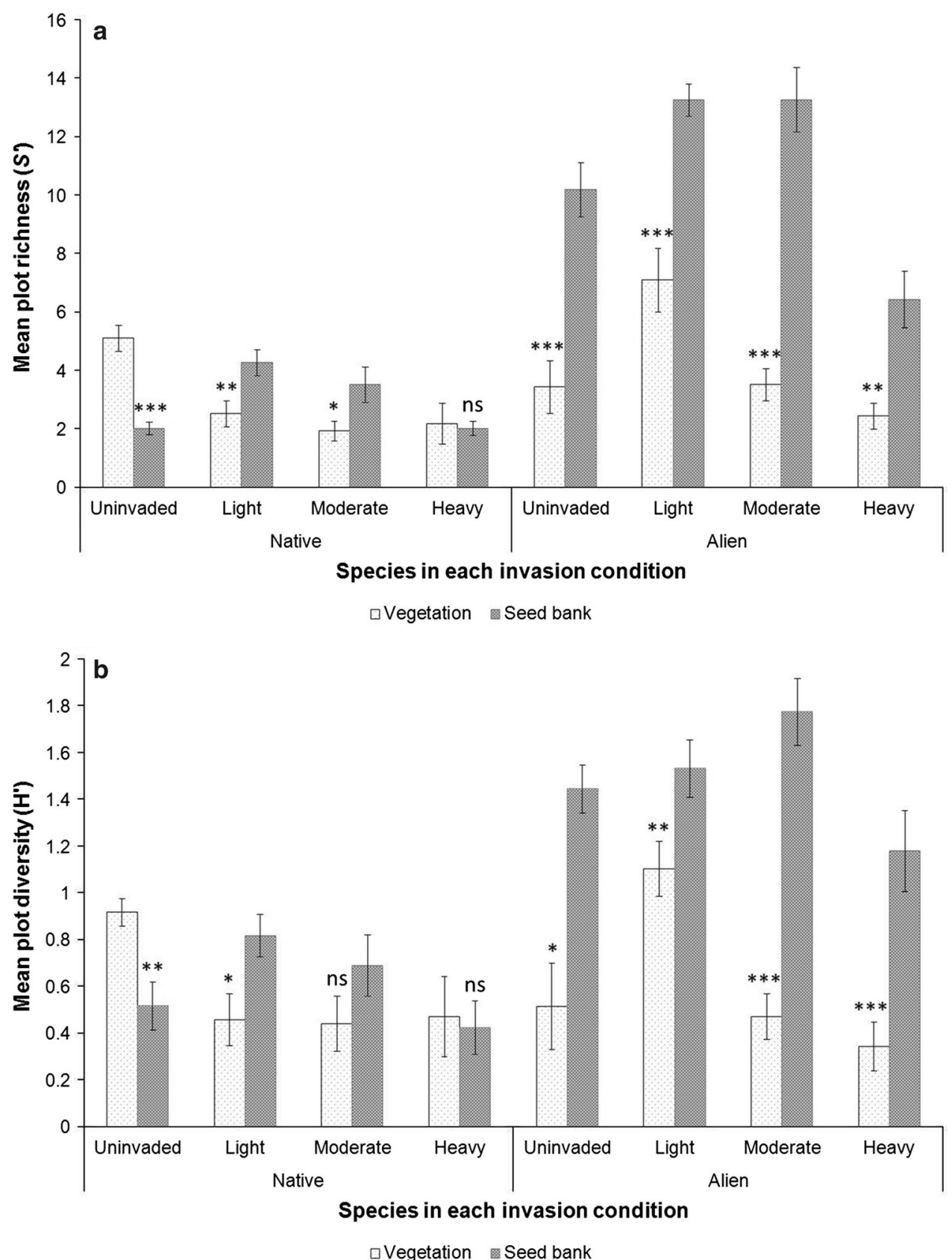

Native species richness varied among invasion conditions which could be explained by comparatively higher number of species in lightly and moderately invaded sites, with relatively open canopy cover (Tererai et al. 2013). Soilstored seed banks occurring in disturbed areas with relatively open vegetation canopy which allows more light penetration to forest floor undergrowth exhibit a high richness and diversity of species, mainly forbs (Luzuriaga et al. 2005).

Our results show that soil-stored seed banks can potentially aid ecosystem restoration. However, restoration activities might be compromised by the low representation of native and the high representation of alien species in the soil seed bank. Soil-stored seed banks of degraded sites are often characterized by severe depletion of richness and abundance of native (especially woody) species (Galatowitsch and Richardson 2005; Reinecke et al. 2008; Meers et al. 2012) which can be explained by prolonged and frequent disturbances such a flooding and alien species invasions (Esler et al. 2008; Holmes and Cowling 1997; Richardson et al. 2007). Additionally, many Eucalyptus species produce allelopathic substances which may constrain the growth and reproduction of understorey plants (del Moral and Muller 1970, Zhang et al. 2010). However, 
it may simply be that native (especially woody) species never form a large and persistent seed bank in this ecosystem (Greet et al. 2013). A depauperate seed bank lacks resistance to primary and secondary invasions (Gioria et al. 2012). The higher degree of dissimilarity of native species among invasion conditions suggests that native species have been affected more than alien species. This finding concurs with those of Holmes and Cowling (1997), Holmes (2002), and Vosse et al. (2008). The fact that natives are affected more than aliens is not surprising because alien species have life-history traits that predispose them to persist in the face of unpredictable disturbance (Truscott et al. 2006). Most native species in the seed bank were shrubs, forbs, and graminoids, whereas alien species were dominated by trees and forbs. The most widespread alien species were an invasive tree, $A$. mearnsii with seed longevity $>50$ years (Holmes 1989) (although not in uninvaded sites), and a forb, $S$. retroflexum occurring in all invasion conditions. The dominance of a few alien species in soil-stored seed banks is a common finding in many studies of invasive alien plants in areas with high disturbance regimes (Esler et al. 2008; Reinecke et al. 2008; Gioria et al. 2011, 2014) and poses significant challenges with secondary invasions (Bakker and Wilson 2004; Ruwanza et al. 2013; Gioria et al. 2014). Although E. camaldulensis is dominant in the above-ground vegetation especially in moderately and heavily invaded sites, it appeared to have a small seed bank. This may be ascribed to a short-lived seed bank typical of the genus Eucalyptus and poor seedling survival under shaded conditions leading to seed bank depletion (Rejmánek and Richardson 2011; Booth 2012; Tererai et al. 2013). Eucalyptus, however, has a high potential to resprout (Nicolle 2006), and this may be a threat to autogenic native vegetation recovery. Appropriate follow-up interventions will be needed to reduce this potential threat.

The soil-stored seed bank is likely to offer a comparatively limited contribution toward native vegetation recovery (agreeing with the findings of Greet et al. 2013) because of the low correspondence between species in the seed bank and above-ground (Holmes and Richardson 1999). This pattern is consistent with reports of low species similarity between the soil-stored seed bank and above-ground vegetation across ecosystems, including wetlands (see Hopfensperger 2007 for a review). The fact that the soil-stored seed bank was more diverse than above-ground vegetation, consistent with the findings of Holmes and Cowling (1997) in the fynbos biome of South Africa, Díaz-Villa et al. (2003) in Mediterranean Spain and French et al. (2011) in Australian coastal dunes, is more of a threat than a merit to restoration because of the dominance of alien species (Esler et al. 2008; Ruwanza et al. 2013). The influence of hydrochory (seed dispersal in water), bringing in seed of species that are not present in established vegetation (Bakker et al. 1996; Vogt et al. 2006) may explain the generally higher diversity of species in the soil-stored seed bank. The occurrence of native tree and shrub species in small numbers in the soil-stored seed bank may indicate suppressed reproductive capacity of native species (del Moral and Muller 1970; Holmes 2002; Tererai et al. 2013). However, we do not rule out the possibility that seeds of trees and shrubs dominant in the aboveground vegetation, e.g., K. africana, D. glabra, and $\mathrm{O}$. europaea ssp. africana were actually present in the seed bank, but may require specific germination cues (Holmes and Cowling 1997; Williams et al. 2008) that were absent in the range of conditions that we provided. We also assume that no seeds were lost during sieving because we used a sieve with holes big enough to let the seeds of all native tree and shrub species through.

Natural riparian vegetation recovery can happen in two possible ways. The first pathway is from a diverse native soilstored seed bank that still exists (although it may not contain all the species in established vegetation), but as discussed earlier, autogenic ecosystem recovery from seed recruitment may be hampered by low native seed densities and the challenge of secondary invasions (French et al. 2011; Gioria et al. 2014). The small numbers of tree and shrub species in the seed banks are of special concern as these have been identified as key species for restoration of riparian vegetation, given their above-ground dominance in uninvaded sites in comparison to other growth forms (Meek et al. 2010; Tererai et al. 2013). The second and most probable (possibly quicker) pathway is recovery from the above-ground remnant native species that currently co-exist with $E$. camaldulensis and usually remain after clearing. Quick establishment of native tree and shrub canopy is critical in order to suppress micro biophysical conditions created by clearing riparian corridors and may likely favor secondary invasions (Galatowitsch and Richardson 2005). We thus highlight the importance of keeping intact patches of native species which may re-establish and commence seed production and recruitment, in order to reduce the need for active restoration, costs for which are often prohibitive (Reinecke et al. 2008). It may also be necessary to reintroduce some native taxa and growth forms that were not represented in the seed bank (e.g., P. elongatus and M. oleoides). This will facilitate recovery of a complete mosaic of species for an optimally functional ecosystem (Vosse et al. 2008). A third potential pathway that we did not investigate is the augmentation of the soil-stored bank from external sources, including upstream sites (Galatowitsch and Richardson 2005); this pathway is likely to introduce non-target species as dispersal methods do not differentiate between native and alien seeds.

The challenge with restoring the vegetation of riparian sites is to ensure that propagules of non-target (non-native) species are kept out of cleared sites. The use of machinery 
for clearing, which is necessary for large tree invaders such as eucalypts, usually exposes seeds buried deep in the soil and triggers germination of IAPs that have a superior competitive edge to exploit favorable microsites (BaattrupPedersen et al. 2012). This necessitates the integration of monitoring and follow-up clearing (possibly hand-pulling and herbicide application) into restoration programs of riparian zones (Esler et al. 2008; Holmes et al. 2008; Flory and Clay 2009). Tererai et al. (2013) suggested a reduction of E. camaldulensis density, as opposed to total clearing, to provide a buffer to inhibit the proliferation of alien species that constrain native vegetation recovery (see also $\mathrm{Ru}$ wanza et al. 2013). No substantial legacy effects are expected after clearing of $E$. camaldulensis since allelopathic chemicals are readily leached from the soil (May and Ash 1990), and soil physico-chemical properties have not been significantly altered by the presence of the eucalypts (Tererai et al. 2014), and soil-water repellency induced by $E$. camaldulensis in these systems does not persist long after stands are cleared (Ruwanza et al. 2013).

\section{Conclusions}

Information gained in this study has important implications for the formulation of improved strategies for enhancing the conservation status of degraded riparian ecosystems invaded by E. camaldulensis. Successful restoration programs of degraded ecosystems depend on a comprehensive assessment of the type and extent of degradation, as well as remnant native species and a viable soil-stored seed bank. Several crucial aspects emerge from this study. Firstly, $E$. camaldulensis forms a small short-lived seed bank which makes local eradication achievable. Regular follow-up operations will be crucial since eucalypts resprout (Nicolle 2006; Rejmánek and Richardson 2011). Secondly, the diverse soil-stored seed bank of native species and remaining patches of native species in the above-ground vegetation are both important for driving restoration. Thirdly, the knowledge of the composition of the postclearing soil-stored seed bank is important for planning to deal with possible germination and establishment of nontarget species, especially important invasive species such as $A$. mearnsii which are abundant in the seed bank. Further investigations on temporal seed bank dynamics are needed to improve our understanding of the role of hydrochory which potentially plays an important role of augmenting the soil-stored seed bank from riparian areas upstream.

Acknowledgments This work was funded by the DST-NRF Centre of Excellence for Invasion Biology (C.I.B) and the Working for Water Programme through their collaborative research project on "Research for Integrated Management of Invasive Alien Species". F.T also thanks the Oppenheimer Memorial Trust for additional funding (OMT Ref. 19362/01 and 19362/02 to F.T.). D.M.R. acknowledges support from the National Research Foundation (Grant 85417). We are grateful to Patricia Holmes for her advice and insightful comments during the project, to Suzaan Kritzinger-Klopper for technical support and assistance in liaising with landowners, and Sheunesu Ruwanza and Joseph Hamuyuni for general assistance.

\section{References}

Baattrup-Pedersen A, Dalkvist D, Dybkjær JB, Riis T, Larsen SE, Kronvang B (2012) Species recruitment following flooding, sediment deposition and seed addition in restored riparian areas. Restor Ecol 21:399-408

Bakker JD, Wilson SD (2004) Using ecological restoration to constrain biological invasion. J Appl Ecol 41:1058-1064

Bakker J, Poschlod P, Strykstra R, Bekker R, Thompson K (1996) Seed banks and seed dispersal: important topics in restoration ecology. Acta Bot Neerl 45:461-490

Beater MMT, Garner RD, Witkowski ETF (2008) Impacts of clearing invasive alien plants from 1995 to 2005 on vegetation structure, invasion intensity and ground cover in a temperate to subtropical riparian ecosystem. S Afr J Bot 74:495-507

Booth TH (2012) Eucalypts and their potential for invasiveness particularly in frost-prone regions. Int J For Res 2012:1-7

Bottollier-Curtet M, Planty-Tabacchi A, Tabacchi E (2013) Competition between young exotic invasive and native dominant plant species: implications for invasions within riparian areas. J Veg Sci 24:1033-1042

Brewer JS, Menzel T (2008) A method for evaluating outcomes of restoration when no reference sites exist. Restor Ecol 17:4-11

Bromilow C (2010) Problem plants and alien weeds of South Africa. Briza Publications, Pretoria

Brudvig LA (2011) The restoration of biodiversity: where has research been and where does it need to go? Am J Bot 98:549-558

Cui N, Wu J, Xiang D, Cheng S, Zhou Q (2013) A field study on seed bank and its potential applications in vegetation restoration of a polluted urban river in China. Ecol Eng 60:37-44

Décamps H, Pinay G, Naiman RJ, Petts GE, McClain ME, HillbrichtIlkowska A, Hanley TA, Holmes RM, Quinn J, Gibert J (2004) Riparian zones: where biogeochemistry meets biodiversity in management practice. Pol J Ecol 52:3-18

del Moral R, Muller CH (1970) The allelopathic effects of Eucalyptus camaldulensis. Am Midl Nat 83:254-282

Díaz-Villa MD, Marañón T, Arroyo J, Garrido B (2003) Soil seed bank and floristic diversity in a forest-grassland mosaic in southern Spain. J Veg Sci 14:701-709

Esler KJ, Holmes PM, Richardson DM, Witkowski ETF (2008) Riparian vegetation management in landscapes invaded by alien plants: insights from South Africa. S Afr J Bot 74:397-400

Fisher JL, Loneragan WA, Dixon K, Veneklaas EJ (2008) Soil seed bank compositional change constrains biodiversity in an invaded species-rich woodland. Biol Conserv 142:256-269

Flory SL, Clay K (2009) Invasive plant removal method determines native plant community responses. J Appl Ecol 46:434-442

Forsyth GG, Richardson DM, Brown J, van Wilgen BW (2004) A rapid assessment of the invasive status of Eucalyptus species in two South African provinces. S Afr J Sci 100:75-77

Fourie S (2008) Composition of the soil seed bank in alien-invaded grassy fynbos: potential for recovery after clearing. S Afr J Bot 74:445-453

French K, Mason TJ, Sullivan N (2011) Recruitment limitation of native species in invaded coastal dune communities. Plant Ecol 212:601-609 
Gaertner M, Den Breeÿen A, Richardson DM (2009) Impacts of alien plant invasions on species richness in Mediterranean-type ecosystems: a meta-analysis. Prog Phys Geogr 33:319-338

Gaertner M, Richardson DM, Privett SDJ (2011) Effects of alien plants on ecosystem structure and functioning and implications for restoration: insights from three degraded sites in South African fynbos. Environ Manag 48:57-69

Gaertner M, Holmes PM, Richardson DM (2012) Biological invasions, resilience and restoration. In: Andel J, Aronson $\mathrm{J}$ (eds) Restoration ecology: the new frontier, 2nd edn. WileyBlackwell, Oxford, pp 265-280

Galatowitsch SM, Richardson DM (2005) Riparian scrub recovery after clearing of invasive alien trees in headwater streams of the Western Cape, South Africa. Biol Conserv 122:509-521

Geldenhuys CJ (2008) Practical guidelines for the rehabilitation of forest-related streambank vegetation with removal of invader plant stands along the Berg River. Working for Water [report no. FW-02/08], Western Cape, South Africa

Gioria M, Osborne B (2009) Assessing the impact of plant invasions on soil seed bank communities: use of univariate and multivariate statistical approaches. J Veg Sci 20:547-556

Gioria M, Dieterich B, Osborne B (2011) Battle of the giants: primary and secondary invasions by large herbaceous species. Biol Environ 111:1-17

Gioria M, Pyšek P, Moravcova L (2012) Soil seed banks in plant invasions: promoting species invasiveness and long-term impact on plant community dynamics. Preslia 84:327-350

Gioria M, Jarošík V, Pyšek P (2014) Impact of invasions by alien plants on soil seed bank communities: emerging patterns. Perspect Plant Ecol Evol Syst 16:132-142

Greet J, Cousens RD, Webb JA (2013) Flow regulation is associated with riverine soil seed bank composition within an agricultural landscape: potential implications for restoration. J Veg Sci 24:157-167

Heelemann S, Krug CB, Esler KJ, Reisch C, Poschlod P (2013) Soil seed banks of remnant and degraded Swartland Shale Renosterveld. Appl Veg Sci 20:18-23

Henderson P (2003) Practical methods in ecology. Blackwell, Oxford

Holmes PM (1989) Decay rates in buried alien Acacia seed populations of different density. S Afr J Bot 55:299-303

Holmes PM (2002) Depth distribution and composition of seed-banks in alien-invaded and uninvaded fynbos vegetation. Austral Ecol 27:110-120

Holmes PM, Cowling RM (1997) Diversity, composition and guild structure relationships between soil-stored seed banks and mature vegetation in alien plant-invaded South African fynbos shrublands. Plant Ecol 133:107-122

Holmes PM, Richardson DM (1999) Protocols for restoration based on recruitment dynamics, community structure, and ecosystem function: perspectives from South African fynbos. Restor Ecol 7:215-230

Holmes PM, Richardson DM, Esler KJ, Witkowski ETF, Fourie S (2005) A decision-making framework for restoring riparian zones degraded by invasive alien plants in South Africa. S Afr J Sci 101:553-564

Holmes PM, Esler KJ, Richardson DM, Witkowski ETF (2008) Guidelines for improved management of riparian zones invaded by alien plants in South Africa. S Afr J Bot 74:538-552

Hood WG, Naiman RJ (2000) Vulnerability of riparian zones to invasion by exotic vascular plants. Plant Ecol 148:105-114

Hooper D, Chapin F, Ewel J, Hector A, Inchausti P, Lavorel S, Lawton J, Lodge D, Loreau M, Naeem S, Schmid B, Setälä H, Symstad A, Vandermeer J, Wardle D (2005) Effects of biodiversity on ecosystem functioning: a consensus of current knowledge. Ecol Monogr 75:3-35
Hopfensperger KN (2007) A review of similarity between seed bank and standing vegetation across ecosystems. Oikos 116:1438-1448

Kauffman BJ, Beschta RL, Otting N, Lytjen D (1995) An ecological perspective of riparian and stream restoration in the Western United States. Fisheries 22:12-24

Landenberger RE, McGraw JB (2004) Seed-bank characteristics in mixed-mesophytic forest clearcuts and edges: does" edge effect" extend to the seed bank? Can J Bot 82:992-1000

Le Maitre DC, Gaertner M, Marchante E, Ens EJ, Holmes PM, Pauchard A, O'Farrell PJ, Rogers AM, Blanchard R, Blignaut J, Richardson DM (2011) Impacts of invasive Australian acacias: implications for management and restoration. Divers Distrib 17:1015-1029

Levine JM, Vila M, Antonio CMD, Dukes JS, Grigulis K, Lavorel S (2003) Mechanisms underlying the impacts of exotic plant invasions. Proc R Soc B 270:775-781

Li Y, Donga S, Wena L, Wanga X, Wua Y (2012) Soil seed banks in degraded and revegetated grasslands in the alpine region of the Qinghai-Tibetan Plateau. Ecol Eng 49:77-83

Luzuriaga AL, Escudero A, Olano JM, Loidi J (2005) Regenerative role of seed banks following an intense soil disturbance. Acta Oecol 27:57-66

Manchester SJ, Bullock JM (2000) The impacts of non-native species on UK biodiversity and the effectiveness of control. J Appl Ecol 37:845-864

Marchante HS, Freitas H, Hoffmann JH (2011) The potential role of seed banks in the recovery of dune ecosystems after removal of invasive plant species. Appl Veg Sci 14:107-119

Margalef R (2002) La diversidad y la biodiversidad. In: Pineda FD, De Miguel JM, Casado MA, Montalvo J (eds) La diversidad biológica de España. Prentice-Hall, Madrid, pp 3-6

May F, Ash J (1990) An assessment of the allelopathic potential of Eucalyptus. Aust J Bot 38:245-254

Meek CS, Richardson DM, Mucina L (2010) A river runs through it: land-use and the composition of vegetation along a riparian corridor in the Cape Floristic Region, South Africa. Biol Conserv 143:156-164

Meers TL, Enright NJ, Bell TL, Kasel S (2012) Deforestation strongly affects soil seed banks in eucalypt forests: generalisations in functional traits and implications for restoration. For Ecol Manage 266:94-107

Mitchell RJ, Auld MH, Le Duc MG, Robert MH (2000) Ecosystem stability and resilience: a review of their relevance for the conservation management of lowland heaths. Perspect Plant Ecol Evol Syst 3:142-160

Musil C, De Witt D (1990) Post-fire regeneration in a sand plain lowland fynbos community. S Afr J Bot 56:167-184

Naiman RJ, Décamps H (1997) The ecology of interfaces: riparian zones. Annu Rev Ecol Syst 28:621-658

Naiman RJ, Décamps H, Pollock M (1993) The role of riparian corridors in maintaining regional biodiversity. Ecol Appl 3:209-212

Nicolle D (2006) A classification and census of regenerative strategies in the eucalypts (Angophora, Corymbia and EucalyptusMyrtaceae), with special reference to the obligate seeders. Aust J Bot 54:391-407

Poff B, Koestner KA, Neary DG, Henderson V (2011) Threats to riparian ecosystems in Western North America: an analysis of existing literature. JAWRA 47:1241-1254

Pyšek P, Richardson DM (2010) Invasive species, environmental change and management, and health. Ann Rev Environ Resour 35:25-55

Reinecke M, Pigot A, King J (2008) Spontaneous succession of riparian fynbos: is unassisted recovery a viable restoration strategy? S Afr J Bot 74:412-420 
Rejmánek M, Richardson DM (2011) Eucalypts. In: Simberloff D, Rejmánek M (eds) Encyclopedia of biological invasions. University of California Press, Berkeley, pp 203-209

Richardson DM, Macdonald IAW, Forsyth GG (1989) Reductions in plant species richness under stands of alien trees and shrubs in the fynbos Biome. S Afr For J 149:1-8

Richardson DM, Holmes PM, Esler KJ, Galatowitsch SM, Stromberg JC, Kirkman SP, Pyšek P, Hobbs RJ (2007) Riparian vegetation: degradation, alien plant invasions, and restoration prospects. Divers Distrib 13:126-139

Richter R, Stromberg JC (2005) Soil seed banks of two montane riparian areas, implications for restoration. Biodivers Conserv 14:993-1016

Rosgen D (1994) A classification of natural rivers. Catena 22:169-199

Ruwanza S, Gaertner M, Esler KJ, Richardson DM (2013a) Both complete clearing and thinning of invasive trees lead to shortterm recovery of native riparian vegetation in the Western Cape, South Africa. Appl Veg Sci 16:193-204

Ruwanza S, Gaertner M, Esler KJ, Richardson DM (2013b) The effectiveness of active and passive restoration on recovery of indigenous vegetation in riparian zones in the Western Cape, South Africa. S Afr J Bot 88:132-141

Ruwanza S, Gaertner M, Richardson DM, Esler KJ (2013c) Soil water repellency in riparian systems invaded by Eucalyptus camaldulensis: a restoration perspective from the Western Cape Province, South Africa. Geoderma 200-201:9-17

Shafroth PB, Briggs MK (2008) Restoration ecology and invasive riparian plants: an introduction to the special section on Tamarix spp. in western North America. Rest Ecol 16:94-96

Sieben E, Reinecke M (2008) Description of reference conditions for restoration projects of riparian vegetation from the species-rich fynbos biome. S Afr J Bot 74:401-411

Sîrbu C, Oprea A, Samuil C, Tănase C (2012) Neophyte invasion in Moldavia (Eastern Romania) in different habitat types. Folia Geobot 47:1-15

Tererai F (2012) The effects of invasive trees in riparian zones and implications for management and restoration: Insights from Eucalyptus invasions in South Africa. PhD thesis, Stellenbosch University, South Africa

Tererai F, Gaertner M, Jacobs SM, Richardson DM (2013) Eucalyptus invasions in riparian forests: effects on native vegetation community diversity, stand structure and composition. For Ecol Manag 297:84-93

Tererai F, Gaertner M, Jacobs SM, Richardson DM (2014) Eucalyptus camaldulensis invasion in riparian zones reveals few significant effects on soil physico-chemical properties. River Res Appl. doi:10.1002/rra.2762

Thompson K, Grime J (1979) Seasonal variation in the seed banks of herbaceous species in ten contrasting habitats. $J$ Ecol 67:893-921

Thompson K, Bakker JP, Bekker RM (1997) The soil seed banks of North West Europe: methodology, density and longevity. Cambridge University Press, Cambridge

Truscott AM, Soulsby C, Palmer SCF, Newell L, Hulme PE (2006) The dispersal characteristics of the invasive plant Mimulus guttatus and the ecological significance of increased occurrence of high-flow events. J Ecol 94:1080-1091

Underwood EC, Viers JH, Klausmeyer KR, Cox RL, Shaw MR (2009) Threats and biodiversity in the mediterranean biome. Divers Distrib 15:188-197

Vilà M, Gimeno I (2007) Does invasion by an alien plant species affect the soil seed bank? J Veg Sci 18:423-430

Vilà M, Espinar JL, Hejda M, Hulme PE, Jarošík V, Maron JL, Pergl J, Schaffner U, Sun Y, Pyšek P (2011) Ecological impacts of invasive alien plants: a meta-analysis of their effects on species, communities and ecosystems. Ecol Lett 14:702-708

Vitousek PM, D'Antonio CM, Loope LL, Westbrooks R (1996) Biological invasions as global environmental change. Am Sci $84: 468-478$

Vogt K, Rasran L, Jensen K (2006) Seed deposition in drift lines during an extreme flooding event: evidence for hydrochorous dispersal? Basic Appl Ecol 7:422-432

Vosse S, Esler KJ, Richardson DM, Holmes PM (2008) Can riparian seed banks initiate restoration after alien plant invasion? Evidence from the Western Cape, South Africa. S Afr J Bot 74:432-444

Walck JL, Baskin JM, Baskin CC, Hidayati SN (2005) Defining transient and persistent seed banks in species with pronounced seasonal dormancy and germination patterns. Seed Sci Res 15:189-196

Wali MK (1999) Ecological succession and the rehabilitation of disturbed terrestrial ecosystems. Plant Soil 213:195-220

Williams L, Reich P, Capon SJ, Raulings E (2008) Soil seed banks of degraded riparian zones in southeastern Australia and their potential contribution to the restoration of understorey vegetation. River Res Appl 24:1002-1017

Zhang D, Zhang J, Yang W, Wu F (2010) Potential allelopathic effect of Eucalyptus grandis across a range of plantation ages. Ecol Res 25:13-23 